\title{
Science, Technology, Engineering and Mathematics (STEM): Liberating Women in the Middle East
}

\author{
Samira Ibrahim Islam ${ }^{1, *}$ \\ ${ }^{1}$ Drug Monitoring Unit, King Fahd Medical Research Centre, Abdulaziz University, Jeddah, Kingdom of Saudi Arabia \\ *Correspondence: Drug Monitoring Unit, King Fahd Medical Research Centre, Abdulaziz University, P.O. Box 488, \\ Jeddah 21411, KSA. Tel: 966-503-186-221. E-mail: dmukauh@yahoo.com
}

Received: April 12, 2019

Accepted: May 27, 2019 Online Published: June 24, 2019

doi:10.5430/wje.v9n3p94

URL: https://doi.org/10.5430/wje.v9n3p94

\begin{abstract}
Middle East Region is home to more than 400 million people, representing 5\% of world population, and boasts a workforce of 103 million scattered across 22 countries (Lord, 2016). Sixty five percent of the populations are young aged 25 or under, which puts growing stress on educational, health and social systems. Over the last decade, most Middle East countries put into action many reforms for women's rights and sensitivity toward gender issues. Currently, almost all Middle East countries have ratified the Convention on the Elimination of all Forms of Discrimination against Women (CEDAW). Many nations in the Region shown strong commitment to uplift education and make them accessible to all eligible women. There was also substantial increase in the allocation of funds for education in nearly all Middle East nations. For a balanced national development, women are needed in the various areas where their functions are most suitable. In principle, there are equal opportunities for both genders but social perception and prejudice determine which types of employment are particularly suitable for women or men. Several renowned Middle Eastern women are Physicians, Chemist, Physicist, Engineers, Doctors, Judges, Lawyers, Journalist, Poets, Novelist and even Legislatives (Islam, 2017)
\end{abstract}

Keywords: STEM, education, career, research, Middle East, women

\section{Introduction}

The Middle East is a region in Western Asia, between the eastern shores of the Mediterranean Sea and the Indian Ocean. The following countries are in the Middle East: Algeria, Bahrain, Cyprus, Egypt, Iran, Iraq, Israel, Jordan, Kuwait, Lebanon, Libya, Morocco, Oman, Palestine, Qatar, Saudi Arabia, Sudan, Syria, Tunisia, Turkey, United Arab Emirates, and Yemen. The term "Middle East" was created by the British Foreign Service and used by a United States naval officer in his article in 1902 (teachmideast, 2019).

Middle East countries are well-known for their huge oil reserves, Islamic culture, and affluent history. Islam is the region's major religion although other religious faiths are also well signified.

The region is a home to more than 400 million people and 65 percent of whom is younger than age 25 years old, which is an extraordinary statistic (Lord, 2016).

\subsection{Women in the Middle East}

Some Western countries believe that Muslim (Middle Eastern) women are oppressed by their religion (Islam) thereby force to completely cover themselves when in public, denied education, no freedom of speech, choice, decision making and other basic rights enjoyed by women in other parts of the world. However, these are proven to be misconceptions. Many of these oppressive practices do not come from religion per se, but are part of local cultural traditions. In fact, Islam gives women a number of rights, some were not revel in by Western women until the 19th century e.g. until 1882, women properties in England was given to their husbands when they got married while Muslim women always reserved their own assets. Muslim women can specify conditions in their marriage contracts, such as the right to divorce should their husband take another wife. In many countries, Muslim women keep their own last name after marriage. The Quran explicitly states that men and women are equal in the eyes of God.

The indubitable truth is women worldwide are exerting great efforts against inequality in education, work force 
participation, and family roles.

As per WEF Gender Gap Report, women political empowerment in the region is improving albeit very low, there is a significant improvement of apparently more than double the rate in 2006. Globally, the average percentage of women in parliament is $25 \%$, but across the Middle East as a whole, women only hold $7 \%$ of parliamentary seats (WEF,2014). As per records, there are three countries in the Middle East which had been led by woman at a certain period: Golda Meir, Prime Minister of Israel (1969 -1974); Tansu Çiller, Prime Minister of Turkey (1993-1996) and Sibel Siber, Prime Minister of Northern Cyprus (13 June 2013 - 2 September 2013) however there are at least 13 Muslim countries having women as head of government (Dalia, 2015).

Women are still underrepresented in politics, but their involvement is rising. In the countenance of political unrest and unequivocal bullying to their rights, many Middle Eastern women are raising their participation to make their voices heard.

Women's participation in the workforce is low, at $25 \%$, while the global average for women in the labor force is about 50\% (World Bank, 2019).

Health wise, obesity is epidemic among women in the region (and also, for men) with some of the highest rates of it in the world. Five of the region's countries landed in the Global Top 20 for female obesity. Kuwait ranks 2nd being 55\% of its female population considered obese. In Egypt, 50\% and 20\% of all women and men respectively are obese. Other Middle Eastern countries on the list include the United Arab Emirates (UAE) (42\%), Bahrain (38\%), and Jordan (38\%) (El-Swais, 2015).

\subsection{Women and Higher Education}

Conventionally, higher education is highly valued in the Middle East. Currently, the educational segment performs more significant functions in society since time in memorial. Governments of most Middle East countries give priorities on shifting from didactic learning systems to supplementary collaborative training method and admission to higher education taking into consideration the ever-changing demographics, political contests and economic variation in the region.

The right to education is regarded as necessary for women in the Middle East. Education serves as the key part of approaches to improve individuals' welfare and societies' economic and social development. It will enable Middle Eastern women to become good mothers to their children and active members of their society. Also serve as their gateway to attain better life by enabling them to understand their human rights and consequently protect them against gender discrimination; educated women can effectively raise a new and better generation.

Societal changes and exchanging economic open market requirements are also pushing the augmented interest in higher education. This is in conformity to the statement of the World Bank, "the key to prosperity is a well-educated, technically skilled workforce producing high-value-added, knowledge-intensive goods and services."

Research shows that the average expenditure on education as percentage of the total government expenditure in the Middle East countries during the year 2016, has reached an average of 16\%, higher than that of many developed countries (UIS, 2019). Such figure may tend to increase in time.

In the Middle East, women access to education has enriched significantly over the years, and there are encouraging developments in women's educations. University enrolment rate of women in most Middle East countries even surpasses men (Figure 1). 


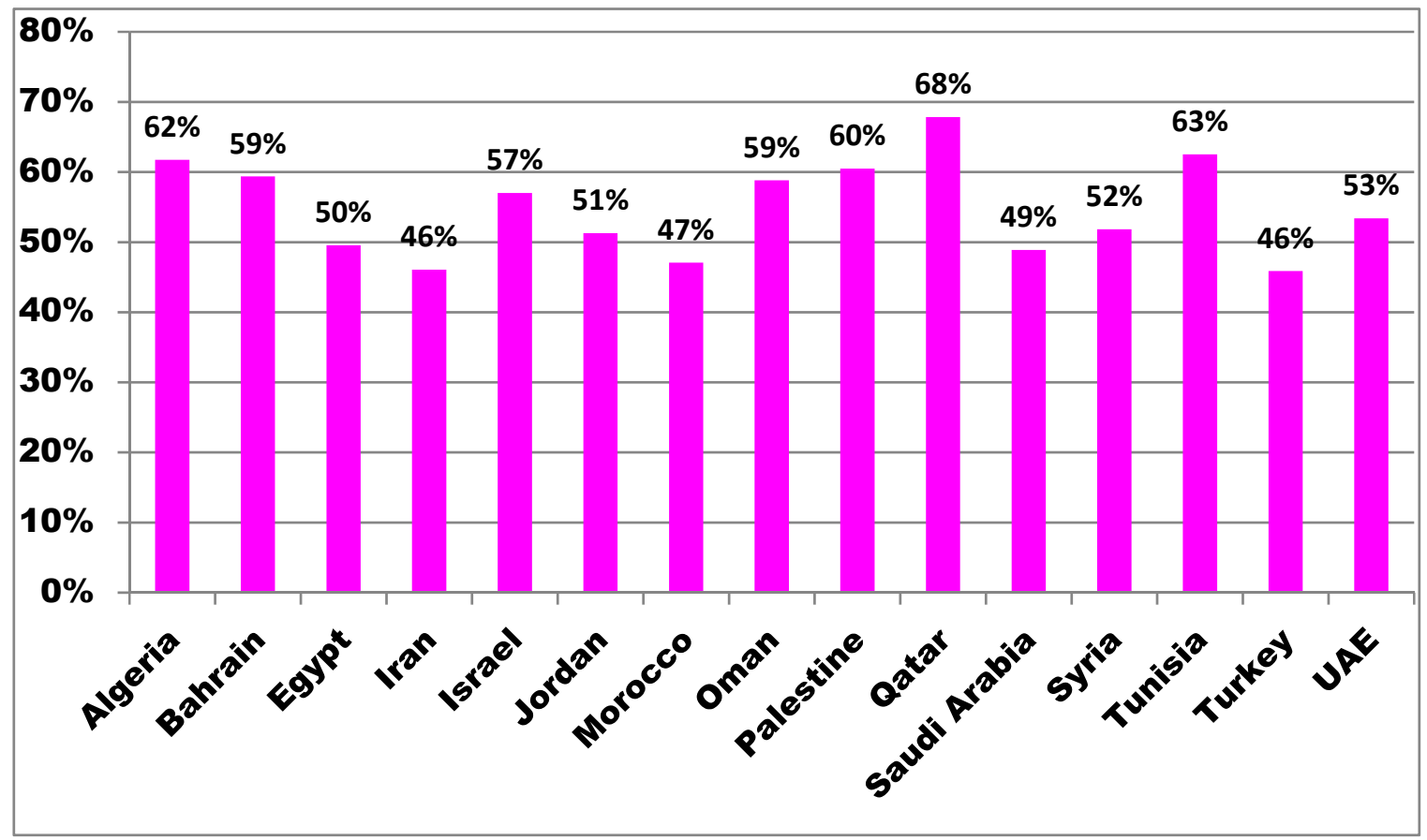

Figure 1. Women's Enrollment as a Percent of Total Students Enrolled in Universities of Some Middle East Countries during SY 2016-2017 (Source: UNESCO Institute of Statistics, 2019)

Such growth will lead to an increasing number of schools and universities in the Middle East particularly the GCC countries, which are expected to escalate from estimated figures of 49,500 institutes in 2010 to more than 55,000 in 2020 (Alpen Capital, 2010).

\section{STEM Education}

Most countries in the Middle East built their economy based on their ideas on innovation, research, science and technology to form the leaders of a knowledge-based and competitive economy.

This is in conformity to what Mr. Roland Hancock (Director for PwC Middle East's education practice) statement, "The importance of STEM education cannot be underestimated and leaders of the future need to be both comfortable and confident in a technical environment. When we look at the world's most successful companies, the clear emerging theme is tech enablement".

STEM fields are rapidly becoming the most in-demand and lucrative in the world. In the Middle East, they are cumulative in fame, with public and private universities creating opportunities for students.

As a result, there is gender equity in STEM fields in the Middle East universities. Meaning women account for almost $50 \%$ or more of the total students involved in STEM. When we look at the percentage of women enrolled and graduated in STEM related fields in 2016, based on the latest statistics published by UNESCO and World Bank, there is no much gender difference and the only STEM field in which men honestly outnumber women is engineering. (Figure $2 \& 3$ ) 


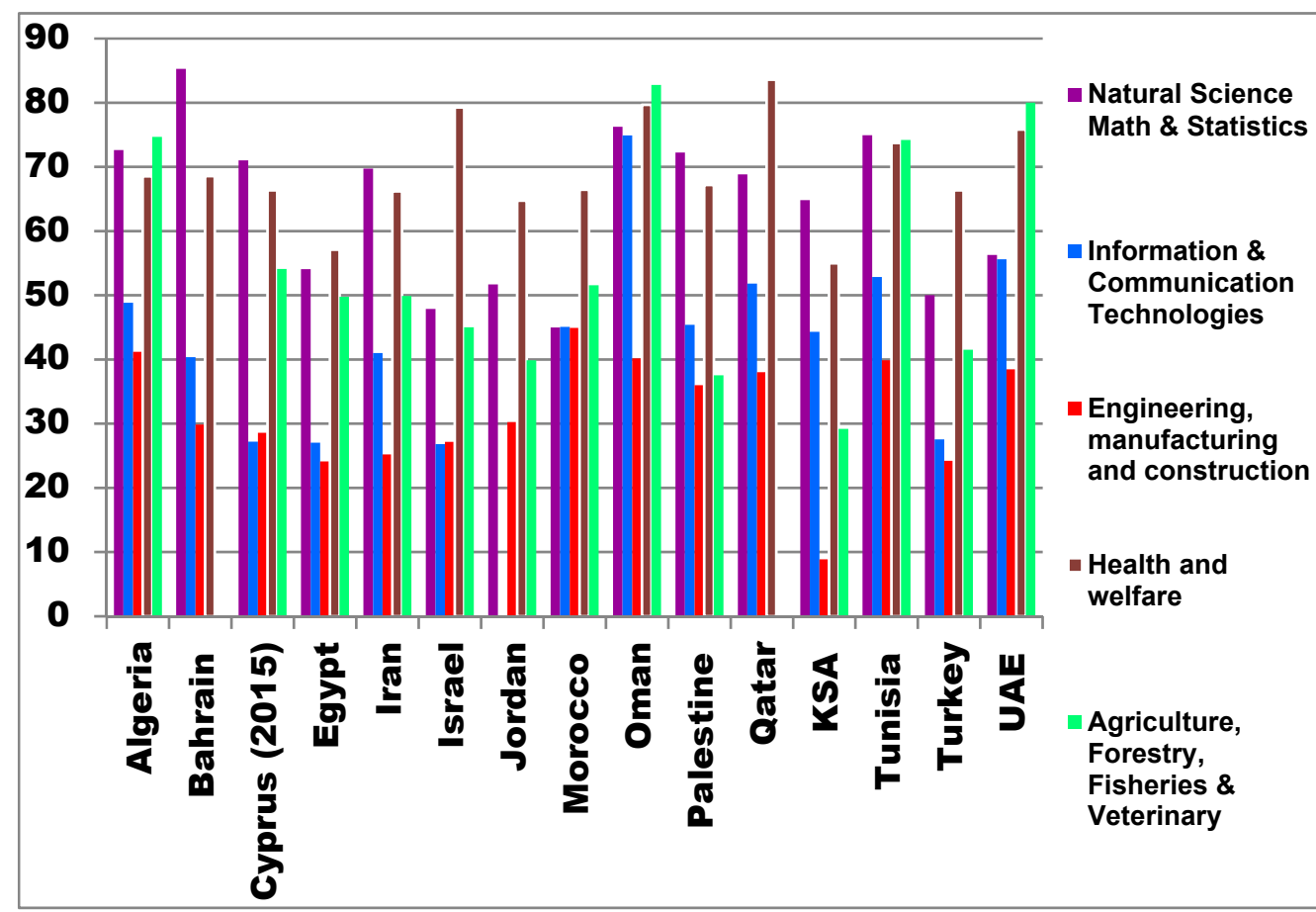

Figure 2. Women Enrolled in STEM Fields as a Percent of All Students, in Some Middle East Countries during SY 2016 - 2017 (Source: UNESCO Institute of Statistics 2019)

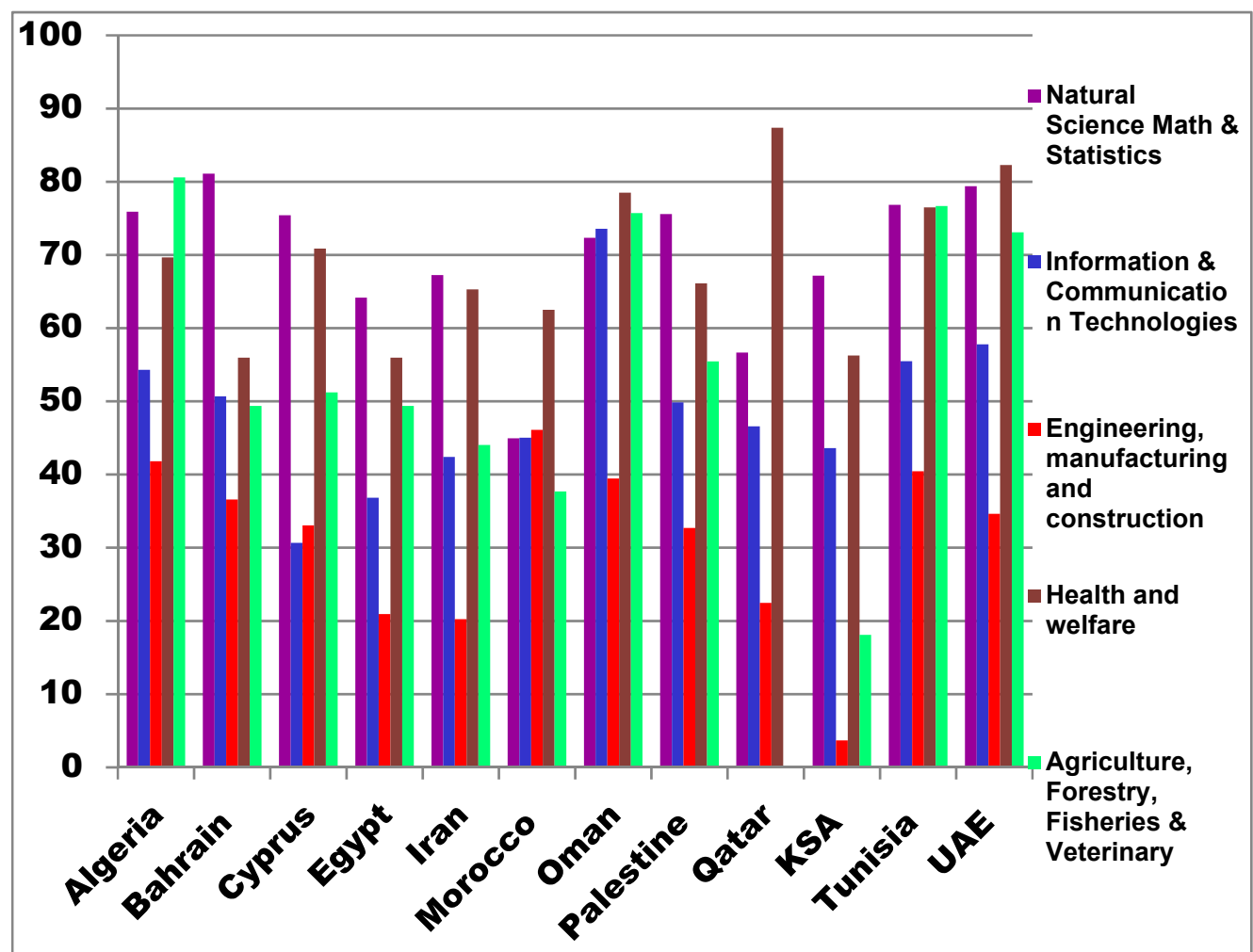

Figure 3. Women Graduated in STEM Fields as a Percent of All Students Graduated in Some Middle East Universities during SY 2016 - 2017 (Source: UNESCO Institute of Statistics 2019) 


\section{Career}

Indicators show that there is a global significant gap between STEM related jobs and STEM graduates. Such observable fact is due to a variety of reasons, foremost of which is the lack of association with aspiration and passion among others.

According to the American Society for Engineering Education, women in the U.S.A. received slightly less than $20 \%$ of the engineering degrees awarded in 2014. Women account for estimated 30\% of the workers at Apple (AAPL), $1.25 \%$ in Face book (FB), and Google parent Alphabet (GOOGL). The share of women decreases as ranks rises (Company diversity data, 2019; Camera, 2015).

It is indubitable that women working in STEM fields are scarce considering that these are one of the world's booming and profitable fields. Policy makers, business leaders and experts often debate the reasons.

Some point out that computer science and engineering courses are male dominated area and offices of technical companies in these fields can be an intimidating place for women to work and offer limited opportunities for them to improve. There is also the issue that very limited women are interested in pursuing careers in STEM. Whatever it maybe, whether due to the dearth of women pursuing STEM work or unfairness against them, both of these issues are entrench in cultural concepts on their interest and ability in these fields.

STEM can provide many opportunities for women in the Middle East as gender diversity has being accepted and technology \& innovation are highly demanded by employers such as the oil and gas, waste management, fast-moving consumer goods and chemical industries. However, there is still great imbalance of women in the labor force considering the percentage of women enrolled and graduates in the STEM fields (Figure 4).

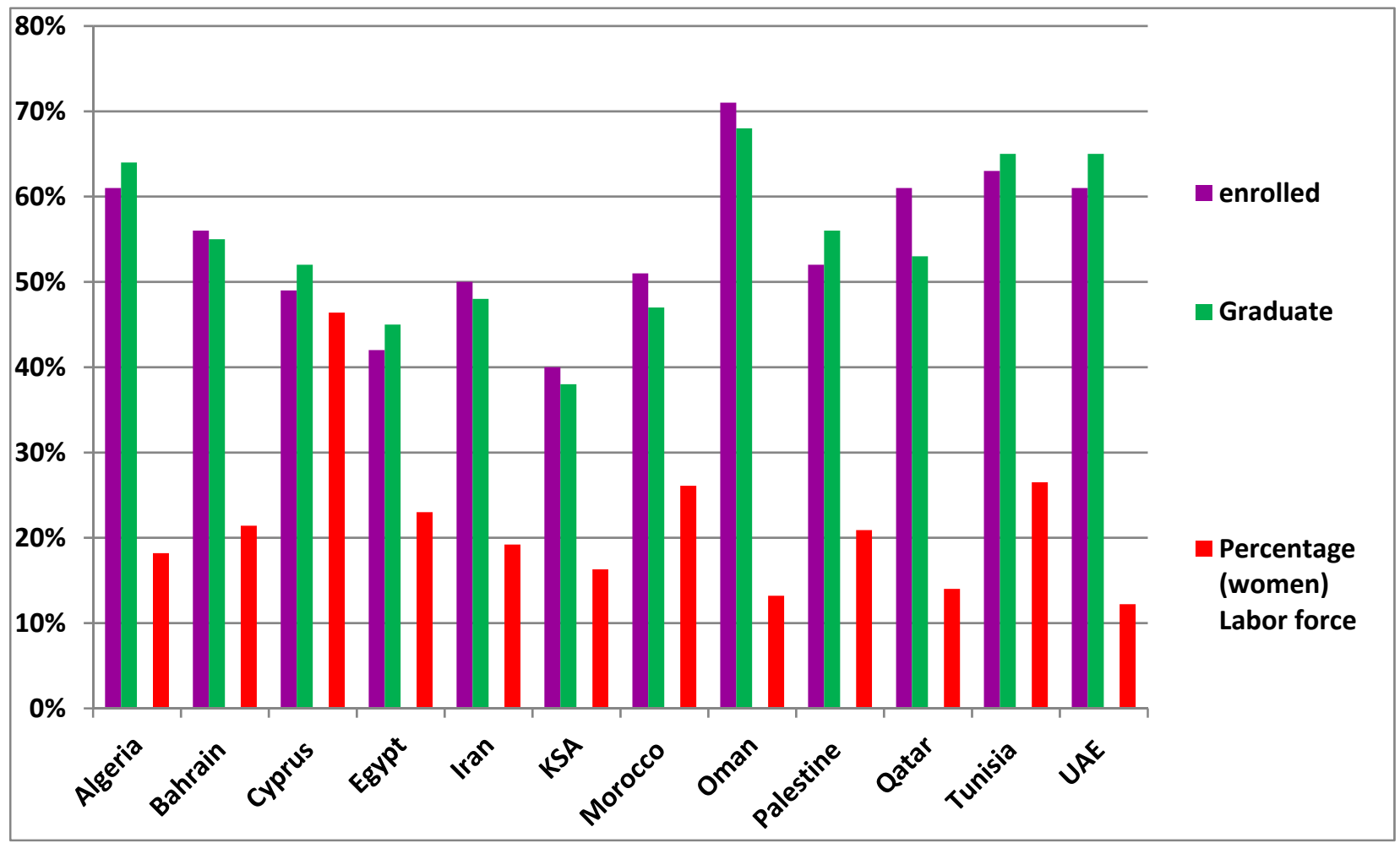

Figure 4. Women Percentage Share: Labor Force VS STEM Education in Some ME Countries in 2016 (Source: UNESCO Institute of Statistics 2019)

Nevertheless, such phenomenon is not limited in the Middle East only but also in developed countries.

According to the U.S. Bureau of Labor Statistics, women shared 47\% of the total U.S. workforce, but are much less represented in STEM related jobs. Women comprise only $39 \%$ of chemists and material scientists, $28 \%$ of environmental scientists and geoscientists, $16 \%$ of chemical engineers and only $12 \%$ of civil engineers (United States 
Department of Labor 2019). In Australia, women shared 12.4\% of the total engineers in their labor force and 20.7\% of those employed in computer software designs and the like were women in 2016 \& 2017 respectively (Kaspura, 2017; Australia Bureau of Statistics 2017). In Canada, women shared $23.1 \%$ of the total professionals in computer and information systems professionals and $13.7 \%$ of the total civil, mechanical, electrical, and chemical engineers in 2016 (Statistics Canada, 2016).

\subsection{Women and Research}

Production of scientific papers in the Middle East has grown nearly four-folds faster than the speed globally. Though, the advancement in scientific publication has been very irregular over the Middle East countries. Iran has the fastest growing research output in the Middle East, increasing the number of scientific publications by 11-times that of the global publication frequency. Turkey ranks second, with a 5.5-times larger than average growth in publication. They are followed by Cyprus, Oman, and United Arab Emirates. Kuwait, Bahrain, Saudi Arabia and Egypt match the global average over the past 3 decades, while growth in Israel and Iraq has been lower than elsewhere (Figure 5) (Habibzadeh, 2011).

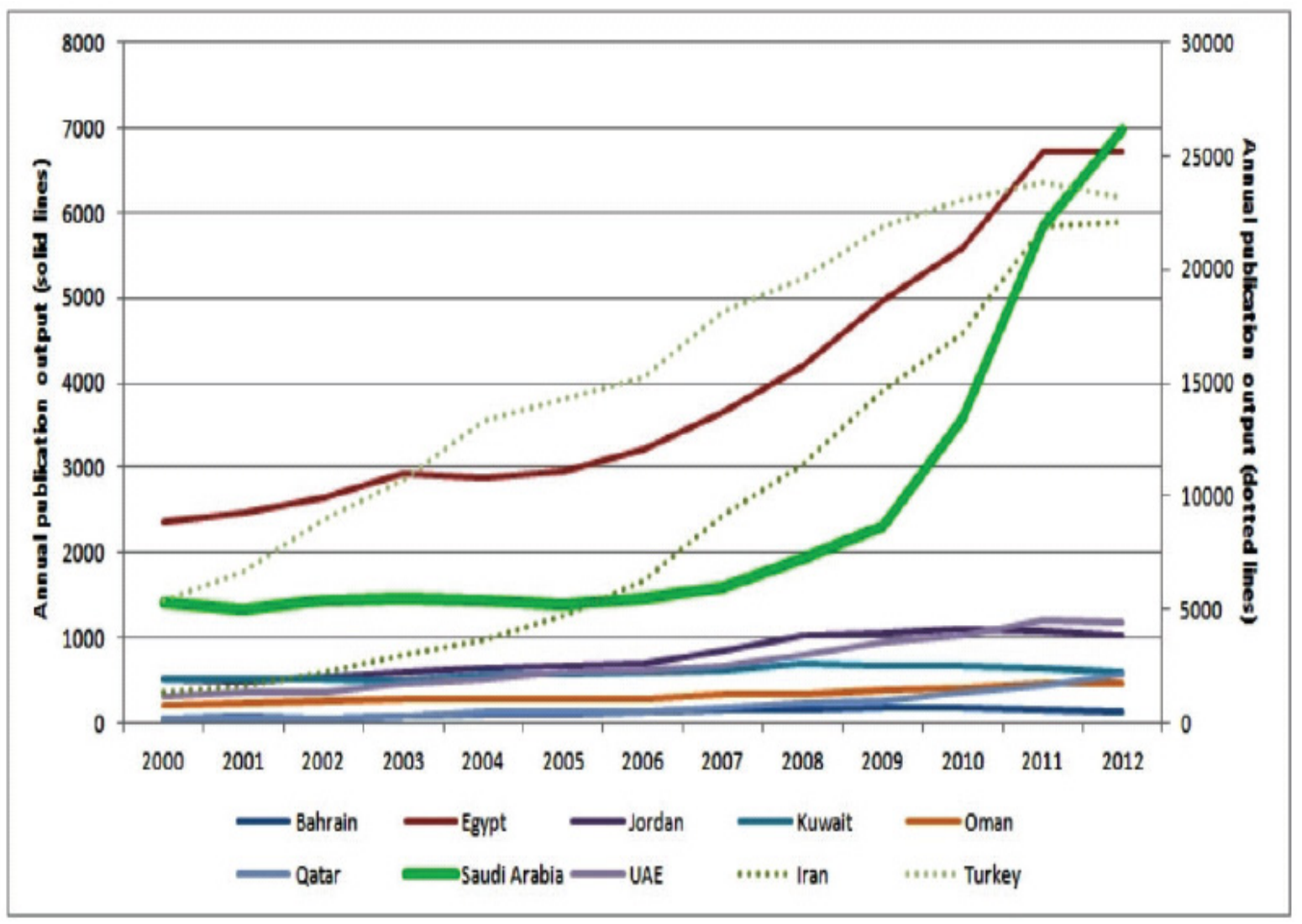

Figure 5. National Research Output Among Leading Research Economies in Some Middle East Countries (Source: KACST, 2015)

Women remain under-represented in the scientific research and those in the field receive less support and less promotion than their male counterpart. The percentage of women graduates in STEM fields is very high across the region, which point toward there is an ample drop between graduation versus employment and research. (Figure $4 \&$ Table 1) 
Table 1. Women Researchers as Percentage of Total Researchers (FTE) in STEM Fields in Some ME Countries (Source: UNESCO Institute of Statistics 2019)

\begin{tabular}{cccccc}
\hline Countries & YEAR & $\begin{array}{c}\text { Engineering \& } \\
\text { Technology }\end{array}$ & $\begin{array}{c}\text { Natural } \\
\text { Sciences }\end{array}$ & $\begin{array}{c}\text { Agriculture, \& } \\
\text { Veterinary Sciences }\end{array}$ & $\begin{array}{c}\text { Medical \& } \\
\text { Health Sciences }\end{array}$ \\
\hline Bahrain & 2014 & 28.3 & 37.5 & & 62.5 \\
Cyprus & 2015 & 31.6 & 37.5 & 31.6 & 38.1 \\
Egypt & 2016 & 30.1 & 40.8 & 35.0 & 47.8 \\
Iran & 2014 & 19.2 & 34.9 & 21.7 & 42.8 \\
Iraq & 2016 & 34.7 & 47.7 & 38.0 & 54.0 \\
Jordan & 2016 & 14.4 & 18.8 & 19.6 & 21.0 \\
Kuwait & 2015 & 37.4 & 50.0 & 26.3 & 52.2 \\
Oman & 2015 & 15.3 & 24.2 & 30.4 & 47.2 \\
Turkey & 2015 & 24.6 & 35.4 & 35.2 & 48.5 \\
Qatar & 2015 & 18.3 & 22.4 & 53.5 & 35.5 \\
\hline
\end{tabular}

But then again, such situation is not limited in the Middle East, even developed countries such as Japan has the same situation. The Japanese government set targets to improve share of women researchers in STEM. In 2006, they established targets for women researchers in science to $20 \%$ and in engineering to $15 \%$. As of 2016, these targets have not yet been met (Government of Japan 2006 \& 2016).

In 2016, undergraduate women in Japan represented just $14.0 \%$ of engineering majors. Only $15.3 \%$ of Japan's researchers in science and technology were women in 2016 (Government of Japan, 2016).

Women enrollment in STEM fields often outstrips men in the Middle East, conversely, this is seems to be the opposite when it comes to career, research in particular. There is a perception in the Middle East society that women have to prioritize family first and due to this societal pressure, women at times select to give up their goals in order to accomplish what the society dictates them.

There are even countries in the Middle East that neither the government nor the private sector supports scientific research.

Poor government supports and research infrastructures often hinder progress (Table 2).

Table 2. Gross domestic Expenditure on R\&D (GERD) as Percentage of GDP of Some Middle East Countries (Source: UNESCO Institute of Statistics 2019)

\begin{tabular}{|c|c|c|c|}
\hline Egypt & 0.71 & K.S.A. & 0.82 \\
\hline Iraq & 0.04 & Tunisia & 0.60 \\
\hline Israel & 4.25 & Turkey & 0.88 \\
\hline Jordan & 0.33 & Oman & 0.25 \\
\hline Qatar & 0.51 & Cyprus & 0.50 \\
\hline World average & 1.70 & Arab States & 0.55 \\
\hline
\end{tabular}

\section{Middle Eastern Women in STEM Fields That Broke the Glass Ceiling}

Role-models hold an important place, to serve as examples for the youth and show them how to use STEM skills to change the world. A survey commissioned by Emirates Global Aluminum, the largest industrial company in the U.A.E. outside oil and gas, revealed in a report in December 2017 that young U.A.E. nationals are increasingly aiming to pursue careers in STEM, but need more high-profile role models and internship opportunities to make this a reality.

Presently, 1 in 5 young people are interested in careers in technology, making it the most popular career goal in today's generation. They feel that access to the acumens and experiences of high-profile people who have had successful careers in STEM would be beneficial to pursuing ambitions in these fields. Additionally, $85 \%$ of young people and $87 \%$ of parents see careers in STEM as more likely to contribute to national development than careers in other fields (Forbes Middle East, 2019).

Contributing to the evolving Science \& Technology landscape in the region, women work in a diverse range of STEM related fields within local and universal contexts.

The following are only some of the many renowned Middle Eastern women that successfully made a name in the 
STEM fields and their numbers are continuously increasing, an adamant representation of liveliness, flicker and interest of women in the Middle East for STEM fields.

Zaha' Hadid (Iraq)

Ghadeer Ibrahim Omar

(Palestine)

Sara Akbar (Kuwait)

Manahel Thabet (Yemen)

Huda Zoghbi (Lebanon)

Maha Ashour Abdalla (Egypt)

Shadia Rifai Habbal (Syria)

Habiba Bouhamed Chaabouni (Tunisia)

Amina Al Rustamani (U.A.E.)
A diva of World Architecture having design and execute major architectural projects e.g. Rosenthal Center for Contemporary Arts (Cincinnati)), BMW plant (Leipzig), bridge linking Abu Dhabi to the mainland of UAE; Awarded the Pritzker Prize (Arhitecture's equivalent to Nobel Prize)

Major scientific leader in the Palestinian Territories; Top Palestinian expert in the field of plant taxonomy; She created the West Bank's first herbarium - a collection of preserved and carefully identified plant species; Conducts research to determine which plants are endangered, and advise the Palestinian Authority on the ecological impacts of development projects in the West Bank

A Petroleum Engineer, member of Kuwait Oil Company since 1981; Played an important role in extinguishing the oil fires after the Gulf war and cleaning up one of the worst environmental disasters in history; Recipient of "Globe 500" Award from the UN Environmental Program

Ranked as one of the 30 Smartest people alive by Super Scholar, Genius of the Year 2014 by the World Genius Directory representing Asia and Brain of the Year Award Winner 2015-2016; The youngest and first Arab woman to obtain a $\mathrm{PhD}$ in Financial Engineering and by writing research papers on quantum mathematics she aims to revolutionize our understanding of math and physics.

The first ME/Arab women scientist to be elected to the National Academy of Sciences (NAS- Houston, USA); Her studies have broadened understanding of diseases of the neurosystem, e.g. Alzheimer and the role of neuron particularly implicated in neuro-denerative behavioural disease e.g. ataxia or loss of balance

Her research spans a range of theoretical problems in the field of space plasma physics; She conceived and developed the approach of using large-scale kinetic (LSK) calculations for studying the magnetotail

Contributed to the development of the first spaceship to the closest possible point near the sun in 2007; Spearheaded an academic movement for women scientist called "Adventurous women"

Devoted her medical and research career in improving conditions of children and families affected by genetic disorder in Tunisia and fought for over 20 years to get medical genetics recognized as an essential discipline in both research medical training; Recipient of UNESCO/L'Oreal "Women in Science “ Award (Africa)

Ranked 9th out of 100 most powerful Arab women in the Middle East in 2015; Electrical engineer by trade, she served as CEO at TECOM Group and is now the current president of the Dubai Institute of Design and Innovation 
Reem Hamdan (Jordan)

Machael el-Shamemre

(K.S.A.)

Ismahane Elouafi (Morocco)

Anousheh Ansari (Iran)

Canan Dağdeviren (Turkey)

Ada Yonath (Israel)
One of only two women in her engineering class of 1991 at the Jordan University of Science and Technology; Currently the Director of Jordan's electrical distribution company, EDCO, responsible for managing the electrical grid in Southern Jordan.

The first Saudi woman to graduate the degree of Astronomical Engineering and join NASA; Her project was to develop a precise weather satellite; She want Saudi women to know that nothing can stand in front of their success as long as they want to prove themselves within their traditions and religion."

Director general, International Centre for Biosaline Agriculture (ICBA), aims to help poor farmers in places where water is scarce, making it a vital lifeline for those working in various parts of the ME/Arab world; Recipient of the National Reward Medal from His Majesty Mohamed VI, the King of Morocco.

The first Muslim woman in space. She wants to inspire ME women and young girls not give up their dreams and to pursue them

A genius scientist at 33; Invented wearable pacemaker and machine that can diagnose skin cancer in 10 seconds; First Turkish doctor selected for the Harvard Young Academy membership

Led the groundbreaking work on the mapping of the structure of ribosomes, using X-ray and crystallography; In 2009 she and her team won the Nobel Prize in Chemistry for their important findings; The first Israeli woman to ever win a Nobel Prize, the first woman in the Middle East to win the prize in the sciences, and the first woman in nearly half a century to win the Nobel Prize for Chemistry.

\section{STEM-Related Awards}

Some of the most prestigious awards in STEM fields are the: Nobel Prize which as of 2018, there are 904 laureates, 51 are women (5.64\%), 20 of whom (39.21\%) are in Science (Nobel Prize Org, 2019); King Faisal International Prize of Saudi Arabia which as of 2018 there are 258 laureates, 7 (2.71\%) are women, 4 (57.14\%) of whom are in Science (Medicine) (King Faizal Org, 2019); Mustafa Prize of Iran- top science and technology award granted every two years to top researchers and scientists in the Islamic world. As of 2018, there are 4 laureates, 1 is a woman. The Fields Medal prize in mathematics, the first woman and first Iranian laureate was Maryam Mirzakhani in 2014 (Mustafa Prize Org, 2019).

UNESCO/L'Oreal "For Women in Science" is an international award recognizes and support renowned women in science throughout the world. As of 2018, there are 102 laureates, 3 of whom have won Nobel Prize for Science as well (L’Oreal, 2019).

\section{Discussion/Recommendation}

There is an immense pool of women endowments in STEM fields considering that they share major percentage of enrolled and graduate students in key universities and colleges in major regions in the world. They are ambitious, eager to be promoted, and dedicated to their professions: $80 \%$ of Americans, $87 \%$ of Brazilians, $90 \%$ of Chinese and $93 \%$ of Indian women in STEM say that they love their work, though a substantial fraction say they feel hindered and are likely to quit their jobs within a year (Hewlette, Sherbin et.al, 2014).

Women are clearly capable of doing well in STEM fields traditionally dominated by men, and they should not be hindered, bullied, or chastened for pursuing careers in such fields. 
Employers should provide reason to re-evaluate women's contribution and representation in these fields because they clearly have the abilities, aptitude and the mind-set to do these STEM related careers.

Policy makers should increase flexibility of employment laws and regulations for more efficient hiring and replacement of workers, embark on researches that focus on gender issues i.e. associate and compare the characteristics, contributions and challenges of women and men. Governments and private sectors should go simultaneously in creating an institutional environment in which women can reach their full potential and with the right combination of enticements and guidelines to keep distinct women betrothed. They should guarantee women's voices are heard in policy formulation. If this will happen, the Middle East region might provide an influential example to the rest of the world.

In spite of women's rights impediments worldwide in 2017, a number of the most exhilarating transformations and optimistic drive came out from the Middle East. Tunisian women have new protections against violence. Women workers in the Gulf countries are armed with new labor protections. The ban on women driving in Saudi Arabia was lifted.

Women in the Middle East have been shattering numerous glass ceilings within contemporary inordinate length of time and traversed a frontier into the "formerly" male-dominated world of STEM fields. This is an exciting time for women in the Middle East.

\section{References}

Alpen Capital. (2010). GCC Education Industry. Retrieved from https://cdn.edarabia.com/wp-content/uploads/2010/09/GCC-Education-Industry-Report-September-2010.pdf

Annual report. (2015). KACST. Retrieved from http://publications.kacst.edu.sa/page/BookDetails.aspx?b=723\&c=6

Australia Bureau of Statistics. (2017). Table 6: Employed Persons by Industry Sub-Division of Main Job (ANZSIC) and Sex," 6291.0.55.003 Labour Force, Australia, Detailed, Quarterly, August 2017, Time Series Spreadsheets. Retrieved from http://www.abs.gov.au/AUSSTATS/abs@.nsf/DetailsPage/6291.0.55.003

Camera L. (2015). Women Still Underrepresented in STEM Fields. Retrieved from https://www.usnews.com

Company diversity data. (2019). Retrieved from http://opendiversitydata.org/

Dalia G. (2015). Meet The Nine Muslim Women Who Have Ruled Nations. Retrieved from https://egyptianstreets.com/2015/06/09/meet-the-nine-muslim-women-who-have-ruled-nations/

El-Swais M. (2015). Ten facts you didn't know about women in the Arab world. Retrieved from http://blogs.worldbank.org/arabvoices/ten-facts-about-women-arab-world

Forbes Middle East. (2018). The future belong to STEM. Retrieved from https://www.forbesmiddleeast.com/the-future-belongs-to-stem

Government of Japan. (2016). The 5th Science and Technology Basic Plan (Provisional Translation).35. Retrieved from https://www8.cao.go.jp

Government of Japan. (2006). Science and Technology Basic Plan (Provisional Translation). 25. Retrieved from https://www8.cao.go.jp/cstp/english/basic

Habibzadeh F. (2011). Geopolitical changes and trends in Middle Eastern countries' contributions to world science over the past three decades. Arch Iran Med 14: 310-11

Hewlett S. A., Sherbin L., et al. (2014). Accelerating Female Talent in Science, Engineering \& Technology. Retrieved from https://www.talentinnovation.org/publication

Kaspura A. (2017). The Engineering Profession: A Statistical Overview. 13: 32. Retrieved from https://www.engineersaustralia.org.au/resource-centre/resource/engineering-profession-statistical-overview-13t h-edition

King Faisal Prize. (2019). Retrieved from https://kingfaisalprize.org/

Lord K. (2016). Here Come the Young. Retrieved from https://foreignpolicy.com

Mustafa Prize Science and Technology Award. (2019). Retrieved from http://mustafaprize.org/laureates

Nobel Prizes and Laureates. Retrieved from https://www.nobelprize.org/prizes/ 
S. I. Islam. (2017). Arab Women in Science, Technology, Engineering and Mathematics Fields: The way Forward. World Journal of Education, 7(6), 12-20. https://doi.org/10.5430/wje.v7n6p12
Statistics
Canada.
2016.
Data
Tables,
2016
Census.
Retrieved from https://www12.statcan.gc.ca/census-recensement/2016

The World needs Science, Science needs Women. Retrieved from https://www.forwomeninscience.com/en/awards

UNESCO Institute of Statistics (2019). Retrieved from http://data.uis.unesco.org

United States Department of Labor. Retrieved from https://www.bls.gov/

What is the Middle East? Retrieved from http://teachmideast.org/articles/what-is-the-middle-east

World Bank. (2019). Retrieved from http://www.worldbank.org

World Economic Forum. (2014). The Global Gender Gap Report. Retrieved from http://www3.weforum.org 